\title{
The metabolism of linoleic acid by the young lamb
}

\author{
By R. C. NOBLE, W. STEELE ANd J. H. MOORE \\ Hannah Dairy Research Institute, Ayr \\ (Received 5 Fuly 1971-Accepted 8 November 1971)
}

\begin{abstract}
I. Groups of lambs were killed immediately after birth; others were reared on a diet of cow's milk and were killed at 10,20 and $30 \mathrm{~d}$ after birth. The concentrations of $18: 2 \omega 6$ (linoleic acid) were determined in cow's milk and the concentrations of $18: 2 \omega 6,20: 4 \omega 6$ (arachidonic acid) and $20: 3^{\omega}\left(\Delta^{6}, 8,11\right.$ eicosatrienoic acid) were determined in the whole carcasses of the lambs.

2. The carcass of the newborn lamb contained only about $300 \mathrm{mg} 18: 2 \omega 6$. During the first $20 \mathrm{~d}$ after birth, there were large increases in the $18: 2 \omega 6$ contents of the carcasses, and on the roth and 20 th days, their contents of $18: 2 \omega 6$ were similar to the dietary intales of I8:2 266 at the corresponding time-intervals after birth.

3. The 20:3 30 to $20: 4 \omega 6$ ratio in the carcass of the newborn lamb was about $1 \cdot 6$, but after ro $d$ the ratio had decreased to 0.38 in spite of the fact that $18: 2 \omega 6$ contributed only about I \% of the total calories in the diet.

4. The minimum dietary requirements for essential fatty acids for young ruminants and for non-ruminent animals are compared.
\end{abstract}

Although the concentrations of $18: 2 \omega 6$ (linoleic acid) in the various tissues of the newborn lamb are very small, it has been shown that there are pronounced increases in the concentrations of this essential fatty acid in the plasma and liver during the first 3-4 d after birth (Leat, 1966; Noble, Steele \& Moore, I971 $a, b$ ). During this period the diet consists entirely of ewe's milk and it has been suggested that one of the functions of ewe's colostrum is to provide the newborn lamb with essential fatty acids (Leat, 1964). However, determinations of the fatty acid compositions of ewe's colostrum and milk secreted during early lactation have shown that the concentration of $\mathrm{r} 8: 2 \omega 6$ never exceeded I \% of the total fatty acids present (Noble, Steele $\&$ Moore, I970). Moreover, it may be calculated that $18: 2 \omega 6$ provides only about 0.4 and $0.5 \%$ respectively of the total calories available to the suckling lamb on the day of parturi-

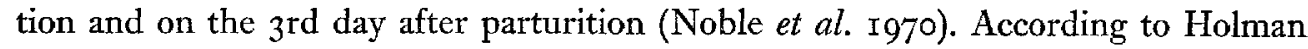
(I960), the minimum requirement for essential fatty acids by the young rat and human infant is met when $\mathrm{I} \%$ of the dietary calories is provided by $\mathrm{I} 8: 2 \omega 6$. Thus, it seems possible that the dietary requirement of the lamb for $18: 2 \omega 6$ is considerably less than that of the young rat and human infant. It is also possible that, in the newborn lamb, there is some store of $\mathrm{I} 8: 2 \omega 6$ in certain tissues other than the plasma and liver and that immediately after birth there is a redistribution of this store. This latter possibility has been investigated in an experiment in which the $18: 2(106$ intakes of lambs have been compared with the $18: 2 \omega 6$ contents of the whole carcasses of the animals up to $3 \circ \mathrm{d}$ after birth. A preliminary account of this work has been given previously (Noble \& Moore, I97I). 
Table $\mathrm{I}$. Live weights $(\mathrm{kg})$ of the lambs from birth to slaughter

\begin{tabular}{|c|c|c|c|c|}
\hline \multirow[b]{2}{*}{ Animal no. } & \multicolumn{4}{|c|}{ Days after birth } \\
\hline & $\circ$ & 10 & 20 & 30 \\
\hline $\mathbf{I}$ & $5 \cdot 17$ & - & - & - \\
\hline 2 & $3 \cdot 58$ & - & - & - \\
\hline Mean & $4 \cdot 3^{8}$ & - & - & - \\
\hline 3 & $3 \cdot 47$ & 5.70 & - & - \\
\hline & 3.70 & $5 \cdot 83$ & - & - \\
\hline Mean & 3.59 & $5 \cdot 76$ & - & - \\
\hline 5 & $4^{\cdot 8 I}$ & $6 \cdot 54$ & $9 \cdot 03$ & - \\
\hline 6 & 5.90 & $7 \cdot 66$ & $9 \cdot 86$ & - \\
\hline Mean & $5 \cdot 36$ & $7 \cdot 10$ & $9 \cdot 44$ & - \\
\hline 7 & $5 \cdot 79$ & $7 \cdot 42$ & $9 \cdot 43$ & 10.8 \\
\hline & $4 \cdot 60$ & $6 \cdot 55$ & $8 \cdot 97$ & $10 \% 7$ \\
\hline Mean & $5 \cdot 20$ & 6.99 & $9 \cdot 20$ & $10 \cdot 8$ \\
\hline
\end{tabular}

EXPERIMEN'TAL

Lambs were obtained from a flock of pure bred Cheviot ewes. The ewes had been given a diet of good hay and concentrates; water was available $a d$ lib. All the lambs were segregated from their mothers at birth and received a diet of cow's milk. One pair of lambs was killed immediately after birth, before access to food; the remaining lambs were killed at intervals of 10,20 and $30 \mathrm{~d}$ after birth, two animals being killed at each time-interval. The lambs were weighed daily and Table I gives the live weight of each lamb immediately before slaughter. The lambs were killed by an intravenous injection of Euthatol (May and Baker Ltd, Dagenham, Essex). Lambs nos. 3-8 received an intramuscular injection of a multivitamin preparation (Crooks Laboratories Ltd, London) on the 2nd day after birth. A uniform homogenate of the carcass of each lamb was obtained by passing the carcass several times through a mincer (Model B 200LF; Wolf King Mincers Ltd, Denmark). The intake of $18: 2 \omega 6$ by each lamb was calculated from the analyses of daily milk samples and a record of the total milk intake at each feeding; replicate analyses of the homogenates of the whole carcasses gave results for the total amounts of fatty acids in all the tissues of each lamb. The concentrations of the fatty acids in the carcass homogenates were determined by the gas-chromatographic procedure described by Christie, Noble \& Moore (1970) using an internal standard. The identities of $18: 2 \omega 6,20: 4 \omega 6$ (arachidonic acid) and $20: 3^{\omega}{ }^{\omega}\left(\Delta^{5}, 8,11\right.$ eicosatrienoic acid) were checked by the gas-chromatographic procedures of Ackman \& Burgher ( $\mathrm{r}_{963}$ ) and Kepler, Hirons, McNeil \& Tove (r 966 ). The properties of the isomers were also compared with authentic standard acids (obtained from the Hormel Institute, Austin, Minnesota, USA) on a gas-chromatograph fitted with a single-flame ionization detector and a support-coated open capillary column $(1525 \mathrm{~cm} \times 0.05 \mathrm{~cm})$ with a stationary phase of diethylene glycol succinate (Perkin-Elmer Ltd, Beaconsfield, Bucks.). The identity of each isomer was checked further by oxidation of the methyl ester fractions (Chang \& Sweeley, I962) and analysis of the resulting mono- and di-carboxylic acids by gas-chromatography as described by Moore \& Williams (1966). On average, I8:2 $2 \omega 6$ accounted for about $80 \%$ of the 
Table 2. Total intakes of $18: 2 \omega 6$ in the diet and total amounts of $18: 2 \omega 6,20: 4 \omega 6$ and $20: 3^{\omega}$ in the carcass homogenates of each lamb at slaughter

\begin{tabular}{|c|c|c|c|c|c|}
\hline \multirow[b]{2}{*}{$\begin{array}{c}\text { Animal } \\
\text { no. }\end{array}$} & \multirow{2}{*}{$\begin{array}{c}\text { Time of } \\
\text { slaughter } \\
\text { (d after birth) }\end{array}$} & \multirow{2}{*}{$\begin{array}{c}\text { Total intake } \\
\text { of } 18: 2 \omega 6 \\
\text { (g) }\end{array}$} & \multicolumn{3}{|c|}{ Total carcass content $(\mathrm{g})$} \\
\hline & & & I $8: 2 \omega 6$ & $20: 4 \omega 6$ & $20: 3^{\omega 0}$ \\
\hline $\mathbf{I}$ & $\circ$ & - & 0.324 & $I \cdot 28$ & 2.06 \\
\hline 2 & o & - & 0.266 & 0.863 & $1 \cdot 36$ \\
\hline Mean & - & - & 0.295 & $1 \cdot 07$ & $I \cdot 7 I$ \\
\hline 3 & IO & $I I \cdot I$ & Io. 6 & $2 \cdot 83$ & $I \cdot I 0$ \\
\hline 4 & ro & 10.7 & 10.5 & $3 \cdot 52$ & $1 \cdot 37$ \\
\hline Mean & - & 10.9 & 10.6 & $3 \cdot 18$ & I $\cdot 23$ \\
\hline 5 & 20 & 23.9 & $26 \cdot 9$ & $6 \cdot 14$ & $1 \cdot 29$ \\
\hline 6 & 20 & 24.9 & $24 \cdot 4$ & $5^{\cdot 02}$ & I. 10 \\
\hline Mean & 一 & 244 & $25 \cdot 6$ & $5 \cdot 58$ & I'I9 \\
\hline 7 & 30 & $35 \cdot 2$ & $26 \cdot 4$ & $7 \cdot 54$ & $x \cdot 28$ \\
\hline 8 & 30 & $36 \cdot 5$ & $25 \cdot 5$ & $8 \cdot 04$ & I.05 \\
\hline Mean & - & $35^{-8}$ & $25^{\circ} 9$ & $7 \cdot 79$ & $x \cdot 16$ \\
\hline
\end{tabular}

total $18: 2$ present in the cows milk given to the lambs; $18: 2 \omega 6$ accounted for $90 \%$ or more of the total $18: 2$ present in the carcasses of the lambs.

\section{RESULTS}

Table 2 shows the total intake of $\mathrm{r} 8: 2 \omega 6$ for each lamb up to the time of slaughter and the total contents of $18: 2 \omega 6,20: 4 \omega 6$ and $20: 3 \omega 9$ in the carcass homogenates of each of the lambs. Since the polyunsaturated acid content of the lambs slaughtered immediately after birth was extremely small, the determination of the $18: 2 \omega 6$ content was subject to some error. For instance, replicate determination of the $18: 2 \omega 6$ content of the carcass homogenate of animals nos. I and 2 ranged from 269 to $360 \mathrm{mg}$ and 237 to $303 \mathrm{mg}$ respectively, resulting in a general mean of $300 \mathrm{mg}$. By the Ioth and 20 th days the amounts of $18: 2 \omega 6$ present in the carcasses had increased considerably and were similar to the dietary intakes of $18: 2 \omega 6$ during these periods. However, on the 3 oth day after birth the total amount of $18: 2 \omega 6$ was similar to that in the lambs killed on the 20 th day after birth, in spite of the fact that the total dietary intake of $18: 2 \omega 6$ had increased by about $10 \mathrm{~g}$ during the period between the 20 th and 3 oth days. On

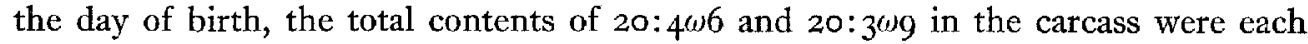
greater than the total carcass content of $18: 2 \omega 6$. During the first $20 \mathrm{~d}$ after birth, the 20:4 46 content of the carcass increased considerably, but this increase was not as marked as that observed for the $18: 2 \omega 6$ content during the same period. However, unlike the $18: 2 \omega 6$ content, the $20: 4 \omega 6$ content of the carcass continued to increase between the 2 oth and 3 oth days after birth. There were no pronounced changes in the total content of $20: 3 \omega_{9}$ in the carcasses of the lambs during the experiment.

\section{DISCUSSION}

To be strictly comparable with previous work (Noble et al. I 97 I $a, b$ ), it would have been better if the experiments now reported had been carried out with lambs suckling 


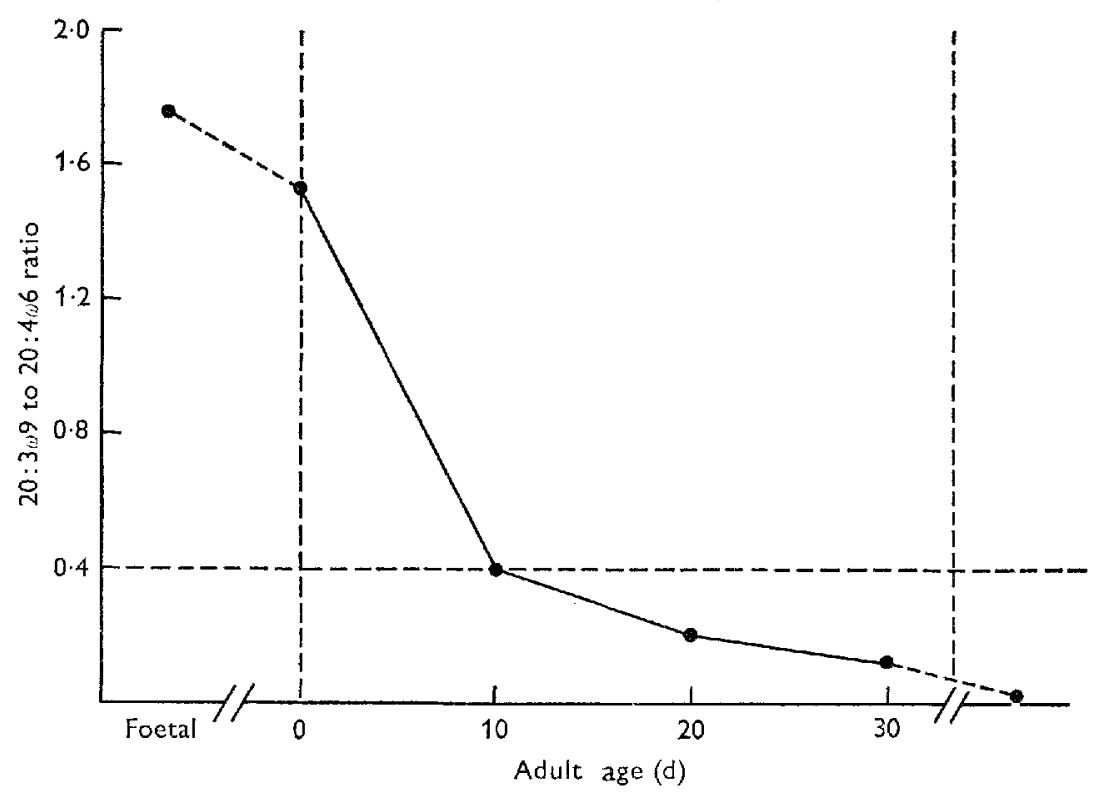

Fig. I. Effect of age on the $20: 3 \omega 9$ to $20: 4 \omega 6$ ratio in the tissues of sheep. Values for foetal and adult tissues are taken from Shorland et al. (1966).

the ewe. However, the difficulties of measuring with any degree of accuracy the I $8: 2 \omega 6$ intake of suckling lambs are considerable, and hence the lambs were handreared on cow's milk. The results given in Table 2 must be viewed in the knowledge that any comparative slaughter techniques are inevitably subject to relatively large errors.

The extremely small amount of $\mathrm{i} 8: 2 \omega 6$ in the carcass of the newborn lamb precludes the possibility of there being any large store of this essential fatty acid in tissues other than the liver and plasma and, since ewe's milk is very low in this acid (Noble et al. I970), it must be concluded that the minimum dietary requirement for $18: 2 \omega 6$ of the young lamb is quite different from that of many other animal species. The essential fatty acid requirement of man and a wide variety of animals is met when $18: 2 \omega 6$ constitutes $I-2 \%$ of the total dietary calorics (Holman, I968). In animals given diets deficient in $18: 206$, the concentrations of $18: 2 \omega 6$ and $20: 4 \omega 6$ in the tissues decrease and the concentration of $20: 3^{\omega} 9$ increases; these biochemical effects are accompanied by the appearance of the characteristic external signs of essential fatty acid deficiency. The 20:3 $3_{9}$ to $20: 4 \omega 6$ ratio in the tissues has been used by Holman (I960) to determine the essential fatty acid status of man and several non-ruminant animals. In general, it may be concluded that the minimum dietary requirement for $18: 2 \omega 6$ has been met when the $20: 3 \omega 9$ to $20: 4 \omega 6$ ratio in the tissues is less than about 0.4 . For instance, the work of Holman ( 1960 ) has shown that, when rats were given a diet in which $18: 2 \omega 6$ supplied only $0 . I_{4} \%$ of the total calories, dermal lesions developed and the $20: 3 \omega 9$ to $20: 4 \omega 6$ ratio in the tissues was about $\mathrm{I} \cdot 0$. When rats were given a diet in which $18: 2 \omega 6$ supplied $5.1 \%$ of the total calories, there were no external signs of essential fatty acid deficiency and the $20: 3 \omega 9$ to $20: 4 \omega 6$ ratio in the tissues was about 
0.06 . Fig. I shows the mean $20: 3 \omega 9$ to $20: 4 \omega 6$ ratios in the carcasses of the experimental lambs, together with corresponding values for foetal lambs and adult sheep calculated from the results of Shorland, Body \& Gass (1966). The high values for the foetal and newborn lambs (I.75 and $\mathrm{I} \cdot 55$ respectively) are of particular interest since ratios of this magnitude in the tissues of the rat and many other non-ruminant species would be associated with external signs of essential fatty acid deficiency. After Io d on a diet of cow's milk, the $20: 3 \omega 9: 20: 4 \omega 6$ ratio in the carcasses of the lambs had decreased to 0.38 , a value that is slightly less than the upper limit $(0.4)$, indicating an adequate essential fatty acid status. Again, this is of interest for, in the cow's milk given to the lambs, I $8: 2 \omega 6$ contributed, on average, only about I $\%$ of the total calories.

The $18: 2 \omega 6$ content of ewe's milk fat is even less than that of cow's milk fat, contributing only about $0.5 \%$ of the total calories in ewe's milk (Noble et al. 1970). Nevertheless, even with lambs reared solely on ewe's milk, the $20: 3 \omega 9$ to $20: 4 \omega 6$ ratio in the liver, for instance, decreased from about $\mathrm{I} \cdot 2$ on the day of birth to about $0.2 \mathrm{on}$ the 8th day after birth (Noble et al. I97 I $b$ ). It appears that, under normal conditions of rearing, just as in the present experiments, the young lamb is able to improve its essential fatty acid status even on a diet that would presumably result in the appearance of external signs of essential fatty acid deficiency in the young rat.

The similarities between the intakes of $18: 2 \omega 6$ from the diet and the increases in the total amounts of $18: 2 \omega 6$ in the carcasses of the lambs during the first and second ro d periods after birth (Table 2) indicate that the absorption and retention of I $8: 2 \omega 6$ by the lamb during the first $20 \mathrm{~d}$ after birth is a highly efficient process. This retention of $\mathrm{I} 8: 2 \omega 6$ by the tissues also implies that there is a high initial requirement for this fatty acid during this period. The results in Table 2 show that there was a marked decrease in the efficiency of retention of $18: 2 \omega 6$ between the 2oth and 3 oth days after birth. It seems that the deficit of $18: 2 \omega 6$ in the tissues of the newborn lamb is made good after about $20 \mathrm{~d}$ on a diet of cow's milk; presumably a somewhat longer period would be required to make good this deficit on a diet of ewe's milk.

It must be remembered that large proportions of the polyunsaturated fatty acids in the diet of the adult ruminant are hydrogenated by the micro-organisms in the rumen (Dawson \& Kemp, I970). In the tissues of the young or adult ruminant, $18: 2 \omega 6$ and other polyunsaturated fatty acids tend to be confined to the phospholipid and cholesteryl ester fractions (Moore \& Steele, I968; Moore, Noble \& Steele, I968; Moore, Steele \& Noble, 1969; Noble et al. 197 $a, b$ ), and it is in these two lipid fractions that the essential fatty acids are believed to play an important part in the structure of biomembranes (Aaes-Jørgensen, I96r; Van Deenen, I966). In the tissues of the nonruminant animal, polyunsaturated fatty acids are more widely distributed among all lipid classes, including the triglycerides (Moore \& Williams, I963; Swell \& Treadwell, 1963) which serve mainly as a store of energy. The highly efficient utilization of polyunsaturated fatty acids for cholesteryl ester and phospholipid synthesis may be the evolutionary mechanism whereby the ruminant animal has become adapted to limited supplies of essential fatty acids from the diet. 
The authors thank Professor D. G. Armstrong, who provided facilities for preparing the carcass homogenates, and Miss A. S. Wallace, Mr D. Patterson and Mr J. McDill for their skilled technical assistance.

\section{REFERENCES}

Aaes-Jørgensen, E. (r96r). Physiol. Rev. 41, I.

Ackman, R. G. \& Burgher, R. D. (1963). F. Chromat. I1, I85.

Chang, T. C. L. \& Sweeley, C. C. (1962). 7. Lipid Res. 3, 170.

Christie, W. W., Noble, R. C. \& Moore, J. H. (x970). Analyst, Lond. 95, 940.

Dawson, R. M. C. \& Kemp, P. (1970). In Physiology of Digestion and Metabolism in the Ruminant p. 504 [A. T. Phillipson, editor]. Newcastle upon Tyne: Oriel Press Ltd.

Holman, R. T. (1960). F. Nutr. 70, 405.

Holman, R. T. (I968). In Progress in the Chemistry of Fats and other Lipids Vol. 9, part 2, p. 279 [R. T. Holman, editor]. Oxford: Pergamon Press Ltd.

Kepler, C. R., Hirons, K. P., McNeill, J. J. \& Tove, S. B. (r966). F. bial. Chem. 24r, r350.

Leat, W. M. F. (I964). Biochem. F. 93, 22 P.

Leat, W. M. F. (1 966). Biochem. F. 98, 598.

Moore, J. H., Noble, R. C. \& Steele, W. (1968). Br. 7. Nutr. 22, 68т.

Moore, J. H. \& Steele, W. (1968). Proc. Nutr. Soc. 27, 66.

Moore, J. H., Steele, W. \& Noble, R. C. (1969). F. Dairy Res. 36, 383.

Moore, J. H. \& Williams, D. L. (1963). Can. F. Biochem. Physiol. 4I, I821.

Moore, J. H. \& Williams, D. L. (1966). Biochem. biophys. Acta 125, 352.

Noble, R. C. \& Moore, J. H. (I97I). Proc. Nutr. Soc. 3o, 6rA.

Noble, R. C., Steele, W. \& Moore, J. H. (r970). 7. Dairy Res. 37, 297.

Noble, R. C., Steele, W. \& Moore, J. H. (1971 a). Lipids 6, 26.

Noble, R. C., Steele, W. \& Moore, J. H. (I97 I b). Br. F. Nutr. 26, 97.

Shorland, F. P., Body, D. R. \& Gass, J. P. (1966). Biochim. biophys. Acta 125, 2 I7.

Swell, L. \& Treadwell, C. R. (1963). In Atherosclerosis and its Origin p. $30 \mathbf{1}$ [M. Sandler and G. H. Bournc, editors]. New York: Academic Press Ltd.

Van Deenen, L. L. M. (1966). In Progress in the Chemistry of Fats and other Lipids Vol. 8, p. I [R. T. Holman, editor]. Oxford: Pergamon Press Ltd. 